\title{
Prevalence of SARS-CoV-2 Antibodies Among Healthcare Workers at a Tertiary Academic Hospital in New York City
}

$J$ Gen Intern Med 35(8):2485-6

DOI: $10.1007 / \mathrm{s} 11606-020-05926-8$

(c) Society of General Internal Medicine 2020

\section{INTRODUCTION}

SARS-CoV-2 antibody testing is important for understanding prevalence of disease exposure and may have implications for healthcare workers (HCW) during the SARS-CoV-2 pandemic. While it remains unknown whether SARS-CoV-2 antibody formation confers immunity, based on patterns seen in other viral illnesses, it is possible IgG presence may protect against reinfection.

HCW in the Mount Sinai Health System, a large, urban, academic tertiary care center, are at high risk for disease exposure as they live in areas with high rates of community spread and work in environments predominantly caring for SARS-CoV-2 patients. ${ }^{1}$ Given limited availability of PCR testing, many $\mathrm{HCW}$ self-diagnose illness and self-isolate until resolution of symptoms, in accordance with the Department of Health guidelines. ${ }^{2}$

We conducted immunologic testing of $\mathrm{HCW}$ to determine the prevalence of SARS-CoV-2 IgG in this population.

\section{METHODS}

We collected serum IgG antibody titers from self-referred HCW throughout our health system using a serologic ELISA assay. ${ }^{3}$ In week 1 , we tested $\mathrm{HCW}$ in departments with the greatest exposure to aerosolized SARS-CoV-2 (i.e., emergency medicine, critical care, anesthesiology), and in week 2 tested all interested $\mathrm{HCW}$ with direct patient exposure. HCW were advised to wait at least 2 weeks from time of symptom onset or suspected exposure before undergoing testing. ${ }^{4}$ All participants were self-reported asymptomatic for at least 3 days at the time of testing. Serum IgG titers were considered "positive" if detected at dilutions of 1:320 or greater and "weakly positive" if detected at dilutions of 1:580 toor 1:160. Titers of 1:320 or greater were eligible for serum plasma donation. One-way ANOVA test and Fisher's exact test were used to compare results among groups. Specimens were collected as part of our convalescent plasma donor identification and treatment program.

Received April 17, 2020

Accepted May 12, 2020

Published online June 3, 2020

\section{RESULTS}

Two hundred eighty-five samples were collected from March 24, 2020, to April 4, 2020. The average age of participants was 38 years (range 18-84), and 54\% were male. Thirty-three percent tested IgG-positive, $3 \%$ tested weakly positive, and $64 \%$ tested negative. Neither age nor sex was associated with antibody development (Table 1). Nine percent were Ab-positive in week 1 versus $44 \%$ in week 2.

\section{DISCUSSION}

Thirty-six percent of HCW had IgG antibodies to SARS-CoV2 , reflecting the high exposure of inpatient and ambulatory frontline staff to this viral illness, most of whom had minimal symptoms and were working in the weeks preceding testing. Interestingly, while $\mathrm{HCW}$ in the first week of our study were in high-risk departments, a larger proportion of HCW in the second week tested positive, likely reflecting the longer time course required for antibody development and the rise in community incidence. A limitation of our study was HCW who were eager to learn their antibody status may have presented too soon after exposure, leading to potential false negative testing. Additionally, it is possible that HCW with higher suspicion of infection were more likely to self-refer, potentially overestimating the rate of antibody positivity.

While we continue to recommend standard protective precautions per CDC guidelines for all $\mathrm{HCW}$, HCW with SARSCoV-2 IgG may become our safest frontline providers as we learn if IgG antibodies confer immunity. Knowing IgG antibody status may ease concerns regarding personal risk as this pandemic continues. The next step will be to screen a larger proportion of our workforce in order to better stratify prior

Table 1 Antibody Results

\begin{tabular}{|c|c|c|c|c|c|}
\hline & \multicolumn{5}{|c|}{ Healthcare worker antibody results } \\
\hline & $\begin{array}{l}\text { All } \\
(N= \\
\mathbf{2 8 5})\end{array}$ & $\begin{array}{l}\mathrm{Ab}+ \\
(N=93)\end{array}$ & $\begin{array}{l}\text { Ab } \\
\text { weakt } \\
(N=9)\end{array}$ & $\begin{array}{l}\mathrm{Ab}- \\
(N= \\
183)\end{array}$ & $\begin{array}{l}p \\
\text { value }\end{array}$ \\
\hline $\begin{array}{l}\text { Age, mean } \\
\text { (SD) }\end{array}$ & $\begin{array}{l}38.36 \\
(10.81)\end{array}$ & $\begin{array}{l}37.15 \\
(12.89)\end{array}$ & $\begin{array}{l}42.67 \\
(8.05)\end{array}$ & $\begin{array}{l}38.63 \\
(9.96)\end{array}$ & 0.291 \\
\hline Age, range & $18-84$ & $18-84$ & $31-55$ & $23-66$ & \\
\hline $\begin{array}{l}\text { Gender } \\
\text { Male, } N\end{array}$ & $111(54)$ & $53(62)$ & $4(50)$ & $54(48)$ & 0.168 \\
\hline $\begin{array}{l}\text { Female, } N \\
\text { (valid \%) }\end{array}$ & $95(46)$ & $33(38)$ & $4(50)$ & $58(52)$ & \\
\hline Test results, 1 & (\%) & & & & \\
\hline $\mathrm{Ab}^{-}$ & $183(64)$ & - & - & - & \\
\hline $\mathrm{Ab}$ weak+ & $9(3)$ & - & - & - & \\
\hline $\mathrm{Ab}+$ & $93(33)$ & - & - & - & \\
\hline
\end{tabular}


exposure based on work environment. Additionally, serial antibody testing will help us better understand duration of IgG response.

Acknowledgments: Thank you to the medical students who assisted with outreaching and following up with our participants.

Mayce Mansour, $M D^{1}$

Emily Leven, $M D^{1}$

Kimberly Muellers, $M P H^{1}$

Kimberly Stone, $\mathrm{MPH}^{1}$

Damodara Rao Mendu, $\mathrm{PhD}, \mathrm{DABCC} \mathrm{C}^{2}$

Ania Wajnberg, $M D^{1}$

${ }^{1}$ Department of General Internal Medicine, Icahn School of Medicine at Mount Sinai,

New York, NY, USA

${ }^{2}$ Department of Pathology, Molecular, and Cell-Based Medicine, Mount Sinai Health System,

New York, NY, USA
Corresponding Author: Mayce Mansour, MD; Department of General Internal Medicine, Icahn School of Medicine at Mount Sinai, New York, NY, USA (e-mail: mayce.mansour@mountsinai.org).

\section{Compliance with Ethical Standards:}

Conflict of Interest: The authors do not have any conflicts of interest to report.

\section{REFERENCES}

1. COVD-19: Data. NYC Health website https://wwwl.nyc.gov/site/doh/ covid/covid-19-data.page. Updated April 13, 2020. Accessed April 14, 2020.

2. New York Department of Health Bulletin. Protocols for essential personnel to return to work following COVID-19 exposure or infection. Albany, NY. Health.ny.Gov. Accessed 31 March 2020.

3. Fatima Amanat, Thi Nguyen, Veronika Chromikova, et al. A serological assay to detect SARS-CoV-2 seroconversion in humans. medRxiv 2020.03.17.20037713. https://doi.org/10.1101/2020.03.17.20037713

4. Juanjuan Zhao, Guan Yuan, Haiyan Wang, et al. Antibody responses to SARS-CoV-2 in patients of novel coronavirus disease 2019, Clin Infect Dis, ciaa344, https://doi.org/10.1093/cid/ciaa344

Publisher's Note: Springer Nature remains neutral with regard to jurisdictional claims in published maps and institutional affiliations. 